\title{
ANALYSIS OF STANDARD OPERATIONAL PROCEDURES (SOP) IN DOING SERVICES AND ITS INFLUENCE ON PATIENT SATISFACTION AT KLINIK MEDAN MEDICAL CENTER
}

\author{
Hablil Ikhwana \\ Faculty of Economics and Business, Universitas Alwashliyah \\ J1. Garu II A, No. 93, Medan \\ E-mail:adegunawan@umsu.ac.id
}

\begin{abstract}
This study aims to find out what are the Standard Operating Procedures (SOPs) that must be applied in providing services to patients at the Klinik medan medical center. How does the application of Standard Operating Procedures (SOP) applied by employees in providing services to patients at the Klinik medan medical center on patient satisfaction. How much influence the application of Standard Operating Procedures (SOP) applied by employees in providing services to patients at the Klinik medan medical center on patient satisfaction. The method used in this study is a quantitative method with several tests, namely reliability analysis, and linear regression. Based on the results of the primary data regression which was processed using SPSS 20, the following simple linear regression equation was obtained: $Y=24.312+0,405 X$. Partially, the SOP variable $(X)$ has a significant effect on patient satisfaction $(Y)$ at the Klinik medan medical center. This means that the hypothesis in this study is accepted, as evidenced by the value of $t$ count $>t$ table $(4.025>1.986)$. The SOP variable $(X)$ is able to contribute to the influence of the patient satisfaction variable $(Y)$ by $39.4 \%$ while the remaining $60.6 \%$ is influenced by other variables not examined in this study. From the conclusions above, the authors suggest that employees and leaders should improve SOPs within the company's internal in order to provide excellent service to patients. Leaders and employees should maintain patient satisfaction by improving clinical facilities.
\end{abstract}

Keywords: SOP and Patient Satisfaction

\section{INTRODUCTION}

The facts on the ground prove that human resources are the most difficult resources in management to manage. This is because human resources, which are then referred to as employees, are creatures of thought that are sometimes different from each other, have different characters and have a lazy nature and at the same time reject what they think is not suitable for them. However, all these problems can be solved by making binding rules so that he is willing to follow and carry out the rules that have been made by the company. In addition to binding rules, companies also need to make standard operating procedures for work. Managing a company with a complex scope of work and diverse human resources is not easy. All of these elements must be maximized properly so that the company's vision and mission can be achieved properly. One thing that can be done is to create a Standard Operating Procedure (SOP). This is not just a rule, but the existence of Standard Operating Procedures (SOP) in a company will be very helpful in the process of developing the company. Even Standard Operating Procedures (SOP) also affect the progress of the company. Because if the Standard Operating Procedure (SOP) is not implemented properly, the impact will also be on employee performance. but the existence of Standard Operating Procedures (SOP) in a company will be very helpful in the process of developing the company. Even Standard Operating Procedures (SOP) also affect the progress of the company. Because if the Standard Operating Procedure (SOP) is not implemented properly, the impact will also be on employee performance. but the existence of 
Standard Operating Procedures (SOP) in a company will be very helpful in the process of developing the company. Even Standard Operating Procedures (SOP) also affect the progress of the company. Because if the Standard Operating Procedure (SOP) is not implemented properly, the impact will also be on employee performance.

In companies that have repetitive or complex jobs, clear rules are needed. The purpose of this regulation is of course to explain in detail how all human resources in the company act in accordance with existing standards and job descriptions. So that in the future there will be an orderly and effective work flow and of course the existence of SOPs can facilitate the work of all existing human resources and if there are new employees, they will also adapt quickly because there are clear regulatory standards. From the management side, it will also be easy to control and supervise the overall workflow. It will be easy to get things that are not fair if you encounter errors. So it will quickly make decisions and solutions to overcome them.

Klinik medan medical center is a general clinic located on J1. Multatuli No. 57 Medan Maimun District, Medan City, North Sumatra. Klinik medan medical center serves a variety of health services such as general poly and dental clinics. In addition, this clinic also has various other supporting facilities such as laboratories, ultrasound, treadmill, EKG, radiology. In carrying out its work operations, the Klinik medan medical center makes Standard Operating Procedures (SOP) in providing services to patients who come. However, there are still employees who do not carry out Standard Operating Procedures (SOP) in providing services to patients properly and correctly so that there are patients who complain about the employee's negligence. Departing from the background of the problem above.

\section{RESEARCH METHOD}

The method used is a questionnaire method. This study uses a qualitative research approach. The place of this research is at the Klinik medan medical center, which is located at Jalan Multatuli No. 57 District of Medan Maimun, City of Medan, North Sumatra. The population of this study were Klinik medan medical center patients based on age ranging from 20 years to 50 years. 20 years as many as 0 respondents, 21-29 years as many as 24 respondents, 30-39 years as many as 35 respondents, 40-49 years as many as 37 respondents, 40-49 years as many as 37 respondents and 50 years and over as many as 0 respondents. The variables used in this study include service SOPs and patient satisfaction. The sampling technique in this study used data analysis techniques in this study including statistical test analysis and linear regression.

\section{RESULTS AND DISCUSSION}

Regression analysis is used to determine whether there is an influence between variables. The following is a summary of the results of simple and multiple regression analysis and path analysis.

Table 1. Statistical Test Results

\begin{tabular}{|ll|l|}
\hline $\mathrm{N}$ & & $\begin{array}{c}\text { Unstandardized } \\
\text { Residual }\end{array}$ \\
\hline \multirow{2}{*}{ Normal Parameters, b } & mean & 96 \\
& Std. Deviation & $0 \mathrm{E}-7$ \\
& Absolute & .98730177 \\
Most Extreme Differences & Positive & .095 \\
& negative & -.112 \\
Kolmogorov-Smirnov Z & & 1.095 \\
asymp. Sig. (2-tailed) & & .181 \\
\hline
\end{tabular}

a. Test distribution is Normal. 
b. Calculated from data.

Source: SPSS Output Version 20 (2021)

Based on table 1 it can be seen that a significance value of 0.181 is greater than 0.05 so it can be concluded that the tested data is normally distributed.

Table 2. Results of Simple Linear Regression Analysis

\begin{tabular}{|l|l|l|l|l|l|}
\hline \multirow{2}{*}{ Model } & \multicolumn{2}{|c|}{$\begin{array}{c}\text { Unstandardized } \\
\text { Coefficients }\end{array}$} & $\begin{array}{c}\text { Standardized } \\
\text { Coefficients }\end{array}$ & \multirow{2}{*}{ t } & \multirow{2}{*}{ Sig. } \\
\cline { 2 - 4 } & \multicolumn{1}{|c|}{ B } & Std. Error & Beta & & \\
\hline (Constant) & 24,312 & 4.213 & & 5.771 & .000 \\
SOUP & .405 & .101 & .383 & 4.025 & .000 \\
\hline
\end{tabular}

a. Dependent Variable: Satisfaction

Based on table 2, it can be seen that the constant value (a) $=24,312$ indicates a constant value, where if the SOP variable $(X)=0$ then the patient satisfaction variable $(Y)=24.312$, meaning that if the Klinik medan medical center patient SOP is applied, it will have patient satisfaction. (Y) is worth 24,312, and the regression coefficient for the variable SOP $(X)=0.405$ indicates that SOP has a positive effect on patient satisfaction $(\mathrm{Y})$, if the SOP $(\mathrm{X})$ is increased by one unit then patient satisfaction (Y) will also increase by 0.405 .

Table 3. Partial Test Results

\begin{tabular}{|l|l|l|l|l|l|}
\hline \multirow{2}{*}{ Model } & \multicolumn{2}{|c|}{$\begin{array}{c}\text { Unstandardized } \\
\text { Coefficients }\end{array}$} & $\begin{array}{c}\text { Standardized } \\
\text { Coefficients }\end{array}$ & \multirow{2}{*}{ t } & \multirow{2}{*}{ Sig. } \\
\cline { 2 - 4 } & \multicolumn{1}{|c|}{ B } & Std. Error & Beta & & \\
\hline (Constant) & 24,312 & 4.213 & & 5.771 & .000 \\
SOUP & .405 & .101 & .383 & 4.025 & .000 \\
\hline
\end{tabular}

a. Dependent Variable: Satisfaction

Source: SPSS Output Version 20 (2021)

Based on table 3, it can be seen that the calculated $t$ value is then compared with the table value at $=0.05$. The value of $t$ table in $\mathrm{df}(\mathrm{nk})$ where $\mathrm{n}$ is the number of samples and $\mathrm{k}$ is the number of variables, both independent and dependent variables, then 96-3 = 93. In df 93 with $=0.05$ the value of $t$ table is 1.985 . The $t$ value of the SOP variable $(X)$ is 4.025 , thus $t$ count $>t$ table, then $\mathrm{H} 0$ is rejected and $\mathrm{H} 1$ is accepted which means that the SOP variable (X1) has a significant effect on patient satisfaction (Y).

\section{CONCLUSION}

From the research conducted, the following results were found: 1) The constant value (a) = 24,312 indicates a constant value, where if the SOP variable $(X)=0$ then the patient satisfaction variable $(\mathrm{Y})=24.312$, it means that if the patient at the Klinik medan medical center, the SOP is applied. it will have patient satisfaction (Y) worth 24,312. The regression coefficient for the SOP variable $(\mathrm{X})=0.405$ indicates that the SOP has a positive effect on patient satisfaction $(\mathrm{Y})$, if the SOP $(\mathrm{X})$ is increased by one unit then patient satisfaction (Y) will also increase by 0.405 . 2) Partially, the SOP $(\mathrm{X})$ variable has a significant effect on patient satisfaction at the Klinik medan medical 
center. This means that the hypothesis in this study is rejected, as evidenced by the value of $t$ count $>\mathrm{t}$ table $(4.025>1.986)$.

From the results of this study, suggestions can be given, firstly, employees and leaders should improve SOPs within the company's internal in order to provide excellent service to patients. Second, leaders and employees should maintain patient satisfaction by improving clinical facilities. Third, employees should work professionally so that the company's goals are achieved and employees are satisfied with the employee's rights.

\section{REFERENCE}

A.S Moenir, 2002, Manajemen Pelayanan Umum di Indonesia, Jakarta : Bumi Aksara.

Arikunto, S. 2006. Prosedur Penelitian Suatu Pendekatan Praktik. Penerbit PT Rineka Cipta, Jakarta.

Azwar, Azrul. 2006. Program Menjaga Mutu Pelayanan Kesehatan : Aplikasi Prinsip Lingkaran Pemecahan Masalah. Jakarta : Yayasan Penerbitan IDI.

Bawono, Anton. 2006. Multivariate Analysis dengan SPSS. Salatiga : STAIN Salatiga Press.

Budiastuti. 2002. Faktor-faktor dalam meningkatkan kepuasan pasien di rumah sakit, http// www//klinis.wordpress//kepuasan pasien terhadap pelayanan keperawatan diunduh pada tanggal 2 januari 2015.

Chase, Richard B., F. Robert Jacobs, and Nicholas J. Aquilano, 2001. Operations Management for Competitive Advantage With Global Cases. 11 edition, MCGraw-Hill International edition, Singapore.

Dwiyanto, Agus. 2008. Mewujudkan Good Governance Melalui Pelayanan Publik. Yogyakarta: Gadjah Mada University Press.

Ekotama, Suryono, 2011. Cara Gampang Bikin Standard Operating Procedure Agar Roda Usaha Lebih Tertata, Yogyakarta: Media Pressindo.

Eny Kusdarini, 2011, Dasar-Dasar Hukum Administrasi Negara dan Asas-Asas Umum Pemerintahan yang Baik, Yogyakarta.UNY Press.

Gerson, Richard F. 2004. Mengukur Kepuasan Pelanggan. Jakarta : Penerbit PPM.

Ghozali, Imam. 2013.Aplikasi Analisis Multivariate Dengan Program IBM SPSS 21 Edisi 7. Semarang: Badan Penerbit Universitas Diponegoro.

Hafizurrachman. 2004. Pengukuran Kepuasan Suatu Institusi Kesehatan. Majalah Kedokteran Indonesia. Volume 54. nomor 7. $283-288$.

Hardiyansyah. 2011. Kualitas Pelayanan Publik Konsep, Dimensi, Indikator dan Implementasinya. Yogyakarta : Gava Media.

Haryanti D.D., Aspriyanto D., \& Dewi I.R. 2000. Efektivitas Menyikat Gigi Metode Horizontal, Vertical, Dan Roll Terhadap Penurunan Plak Pada Anak Usia 911 Tahun. Dentino (Jurnal Kedokteran Gigi). 2(2):151-154 
Heriandi, D. S. O, Aydin Serkan, Ates Mertin, Cetin A. T. 2007. Effects of Service Quality on Costumers Satisfaction and Costumer Loyality: Marmara University Hospital. (Jurnal Elektronik) diakses 6 September 2016

Herianto, J. 2009. Pengukuran Tingkat Kepuasan Pelanggan. Edisi Revisi. Cetakan Ketiga. Jakarta. PT. Rineka Cipta.

Ilyas S, Tansil M and Salamun ZA.2009. Sari Ilmu Penyakit Mata. Jakarta: Balai Penerbit FK UI.

Jacobalis, S. 2009. Menjaga Mutu Pelayanan di Rumah Sakit (Quality Assurance). Jakarta: Persi.

Kottler, Philip. 2007. Manajemen Pemasaran. Klaten: PT Intan Sejati

Kurniawan. 2013. Pengaruh kompetensi pedagogik, dan kompetensi professional Guru: Universitas Pendidikan Indonesia. Pustaka Belajar.

Kusumapradja, R. 2007. Pengaruh Motivasi Kerja Perawat Terhadap Penerapan Program Keselamatan Pasien di Unit Rawat Inap Rumah Sakit X Tangerang Selatan. Jurnal Hospitalia, Volume 1 Nomor 1, Februari 2018.

Lusa, J.S. 2007. Hubungan Quality Assurance dengan Kepuasan Pasien Rumah Sakit diakses dalam http://www.jsofian.com tanggal 3 Desember 2015.

Marajabessy, Yakub. 2008. Analisis Kepuasan Pasien Terhadap Pelayanan Rawat Inap di RSUD Kota Tidore Kepulauan Maluku Utawa. Tesis. Institut Pertanian Bogor : Bogor.

Mediawati, Elis. 2000. Pengaruh Motivasi Belajar Mahasiswa dan Kompetensi Dosen terhadap Prestasi Belajar, Jurnal Pendidikan Ekonomi Dinamika Pendidikan Vol 5 No 2 Desember 2019

Notoatmodjo. 2010. Ilmu Perilaku Kesehatan. Jakarta Rineka Cipta.

Nurrachmah, Elly. 2001. Asuhan Keperawatan Bermutu di Rumah Sakit 29 November 2005. From :file://ElSanitalFile\%20Internet|Pusat\%20 Data\%20\&\%20Informasi \%20PERSI1.htm.

Nursalam. 2001. Pendekatan Praktis Metodologi Riset Keperawatan. Jakarta : CV Sagung Seto.

Ratminto dan Atik Septi Winarsih, 2010, Manajemen Pelayanan : Pengembangan Modul Konseptual, Penerapan Citizen Charter dan Standar Pelayanan Minimal, Yogyakarta : Pustaka Pelajar.

Sabarguna, B. S. 2004. Quality Assurance Pelayanan Rumah Sakit. Edisi Kedua. Yogyakarta: Konsorsium Rumah Sakit Islam Jateng-DIY.

Sinambela, Dr. Lijan Poltak. 2007. Reformasi Pelayanan Publik (Teori, kebijakan dan implementasi). Jakarta: Bumi Aksara.

Soejadi. 2006. Pedoman Penilaian Kinerja Rumah Sakit Umum. Jakarta: Katiga Bina

Supranto, J. 2001. Pengukuran Tingkat Kepuasan Pelanggan Untuk MenaikkanPangsa Pasar, Cetakan keempat, Penerbit PT Rineka Cipta, Jakarta.

Suryawati, J., 2006. Sosiologi Jilid 3. Jakarta: Penerbit ESIS 
Tambunan, Rudi M, 2013. Pedoman Penyusunan Standard Operating Procedures (SOP), Jakarta: Maistas Publishing.

Tjiptono, Fandy. 2005. Strategi Pemasaran. Yogyakarta:Andi Offset

Utama. A. 2003. Analisis Pengaruh Persepsi Kualitas Pelayanan Terhadap Kepuasan Pelanggan Rumah Sakit Umum Cakra Husada Klaten. Vol. 1, No.2.Desember. http://staff.uny.ac.id/sites/default/files/penelitian/Agung\%20Utama,\%20SE.,\%20M.Si./Kualit as\%20Pelayanan\%20RS\%20Cakra\%2 0Husada.pdf

Woodside, AG. and Martin, D. 2008. Tourism Managemenet: analysis behaviour and strategy. Oxfordshire: CAB International. 